\title{
Analisis Logam Berat Cd dan Simbionnya dalam Alga Eucheuma cottoni di Perairan Kabupaten Bantaeng
}

\author{
Muhammad Tasjiddin Teheni
}

Program Studi DIII Farmasi Politeknik Bau-bau, Jl. Lakarambau Kota Bau-bau 93721

E-mail: $\underline{\text { muh.tasjiddin.teheni@gmail.com }}$

\begin{abstract}
Abstrak
Alga merupakan tumbuhan yang hidup diperairan dengan keragaman jenisnya yang pada umumnya mengandung klorofil, tetapi tanpa batang dan akar nyata. Didalam rumput laut juga terdapat bakteri, bakteri ini memiliki peran penting dalam kesinambungan kehidupan di laut. Bakteri memiliki kemampuan untuk mendegradasi senyawa organik menjadi senyawa anorganik yang menjadi sumber makanan bagi fitoplankton yang merupakan piramida dasar dari rantai makanan di laut. Jenis rumput laut di Indonesia yang memiliki nilai ekenomi yang tinggi yaitu Eucheuma Cottoni dimana kabupaten Bantaeng adalah salah satu pusat produksi rumput laut di Sulawesi Selatan. Tujuan penelitian ini adalah mengetahui kadar logam berat kadmium dan simbionnya di perairan Bantaeng. Kadar kadmium dan simbionnya ditentukan dengan menggunakan metode spektrofotometer serapan atom (SSA). Analisis ini dilakukan melalui proses dekstruksi dengan menggunakan $\mathrm{HNO}_{3}$ pekat. Jumlah titik pengambilan sampel sebanyak 6 titik lokasi yaitu desa Nipa-Nipa, Kampung Bakara, Boroloe, Tapaloe, Baruga Utara dan Baruga Selatan. Hasil penelitian menunjukan konsentrasi logam tertinggi pada desa Nipa-Nipa dengan konsentrasi 0,2920 ppm dan terendah pada desa Boroloe yaitu 1,4377 ppm sedangkan konsentrasi simbion logam kadmium yang tertinggi berasa pada desa Baruga Utara dengan konsentrasi 0,0192 ppm dan terendah pada desa Nipa-Nipa yaitu 0,0141 ppm
\end{abstract}

Kata kunci: Alga, simbion, logam berat, Eucheuma cottoni, Bantaeng

\section{Pendahuluan}

Alga merupakan tumbuhan yang hidup di perairan dengan keragaman jenisnya yang pada umumnya mengandung klorofil, tetapi tanpa batang dan akar nyata. Alga dapat dikelompokkan menjadi dua dua kelompok berdasarkan ukurannya. Makroalga atau yang biasa dikenal dengan nama rumput laut dan mikroalga, organisme sel tunggal dengan ukuran bervariasi [1]. Rumput laut merupakan kata untuk menggambarkan alga makroskopis dan multiselululer. Terdapat tiga jenis rumput laut yaitu alga merah, coklat dan hijau [2]. Rumput laut merupakan kompoenen ekosistem perairan yang sangat penting secara ekologi dan memegang peranan penting dalam keragaman pesisir [3].

Selain itu, alga juga mempunyai peranan penting dalam ekosistem terumbu karang. Sebagai produsen primer, alga menambah carrying capacity untuk mendukung ekosistem terumbu karang. Alga merupakan sumber makanan utama bagi ikan herbivora dan sebagai dasar pada jarring makanan di eksosistem terumbu karang [4]. Biomassa yang berasal dari alga telah menarik minat banyak peneliti dikarenakan kandungan karbohidrat dan polisakarida yang menjadikan rumput laut dijadikan bahan pangan dan pupuk [5]. Selain itu penggunaan rumput laut dimanfaatkan pada penelitian seperti digunakan sebagai produksi bioethanol [6], bioakumulasi logam [7], Produksi sebagai antioksidan [8], antibakteri [9], antibiotika [10].
Beberapa logam berat dalam perairan seperti $\mathrm{Pb}$ (timbal), Cd (cadmium), Hg (Merkuri), Zn (Seng) dengan jumlah konsentrasi berlebih merupakan logam beracun dan berbahaya. Logam-logam tersebut termasuk dalam unsur non essensial bagi organisme terutama rumput laut [11]. Pada beberapa logam berat seperti Cu (tembaga), Fe (Besi), Co (kobalt), Mn (Mangan) dan lainnya merupakan jenis logam berat essensial yang dalam kuantitas tertentu sangat diperlukan oleh organisme hidup, terutama rumput laut. Namun, dalam kadar tertentu juga bersifat toksik [12] Mineral yang masih bersifat toksik dan tergolong logam menurut yaitu $\mathrm{As}, \mathrm{Cu}, \mathrm{Cd}$, da $\mathrm{Pb}$ [13].

Beberapa mikroorganisme seperti bakteri juga terdapat pada rumput laut. Bakteri ini memiliki peran penting dalam kesinambungan kehidupan di laut. Bakteri memiliki kemampuan untuk mendegradasi senyawa organik menjadi senyawa anorganik yang menjadi sumber makanan bagi fitoplankton yang merupakan piramida dasar dari rantai makanan di laut. Bakteri simbion dapat berfungsi sebagai akumulator dan digunakan untuk absorpsi logam [14]. Bakteri dapat ditemukan di bagian mana saja di dalam laut yang paling dalam dan kolom sedimen. Bakteri digunakan sebagai indikator polusi logam berat karena sifat logam berat bila dipaparkan secara terusmenerus mudah terakumulasi dan bersifat toksik sehingga menyebabkan kerusakan pada fungsi sel dan metabolisme sel [15]. 
Keberadaan bakteri pada rumput laut berdasarkan penelitian yang telah dilakukan pada alga jenis Pococrikiella variegeta menghasilkan bakteri Pelagiobacter variabilitis digunakan sebagai antibiotik. Alga atau rumput laut digunakan dalam hal metabolit sekunder dan primer diketahui bahwa dalam alga terdapat mikroorganisme yang juga berperan dalam menghasilkan metabolit sekunder dan metabolit primer [16].

Kabupaten Bantaeng sekarang ini dikenal sebagai Kabupaten dengan produksi budidaya rumput laut Eucheuma cottoni yang tinggi. Dari data statistik Dinas Perikanan dan Kelautan tahun 2011 di Kabupaten Bantaeng tercatat jumlah RTP pembudidaya rumput laut yaitu 3,197 orang yang memanfaatkan $2,888,8$ ha. Luas ini berarti $50,7 \%$ dari total wilayah yang bisa dibudidayakan rumput laut ( \pm 5.375 ha) [17]. Tujuan penelitian ini yaitu penentuan kadar kadmium (Cd) dan simbionnya pada rumput laut. Logam tersebut merupakan logam berat yang dalam ambang batas tertentu akan membahayakan dan beracun apabila dikonsumsi.

\section{Metode}

\subsection{Pengambilan Sampel}

Sampel rumput laut diambil di pesisir perairan Kabupatan Bantaeng pada titik pengambilan sampel sebanyak 6 titik

Tabel 1. Titik koordinat lokasi pengambilan sampel

\begin{tabular}{|c|c|c|}
\hline Lokasi Titik Sampling & \multicolumn{2}{|c|}{ Titik Koordinat Sampling } \\
\hline Desa Nipa-Nipa & 5०34'27.3”LS & $120^{\circ} 01^{\prime} 23.8^{\prime \prime} \mathrm{BT}$ \\
\hline Desa Kampung Bakara & 5०34'40.7' LS & $120^{\circ} 02^{\prime} 09.1 ” \mathrm{BT}$ \\
\hline Desa Boroloe & 5०34'46.9”'LS & $120^{\circ} 02^{\prime} 42.8^{\prime \prime} \mathrm{BT}$ \\
\hline Desa Tapaloe & 5०34'54.2” LS & $120^{\circ} 03^{\prime} 19.5 " \mathrm{BT}$ \\
\hline Desa Baruga Utara & $5^{\circ} 35^{\prime} 32.5^{\prime \prime} \mathrm{LS}$ & $120^{\circ} 05^{\prime} 43.9^{\prime \prime} \mathrm{BT}$ \\
\hline Desa Baruga Selatan & $5^{\circ} 35^{\prime} 20.3 \prime \mathrm{LS}$ & $120^{\circ} 05^{\prime} 14.1$ " BT \\
\hline
\end{tabular}

\subsection{Pengujian Sampel Analisis Logam pada Alga Laut}

Sampel dibersihkan dari material pengotor dengan menggunakan aquadest kemudian dikeringkan dalam oven pada suhu $60^{\circ} \mathrm{C}$ sampai berubah menjadi coklat kehitaman. Sampel yang sudah kering kemudian dihancurkan menjadi serbuk dan dihomogenisasi dengan mortar. Sebanyak $5 \mathrm{~g}$ serbuk dimasukkan dalam cawan porselin lalu ditambah 20 $\mathrm{mL} \mathrm{HNO}_{3}$ kemudian didestruksi. Hasil destruksi disaring menggunakan kertas whatman 42 sehingga diperoleh larutan jernih. Filtrat lalu ditempatkan dalam labu ukur 50 $\mathrm{mL}$ dan siap di analisis

\subsection{Pembuatan Deret Standar Cd pada Alga Laut}

Pembuatan deret standar logam $\mathrm{Cd}$ adalah 0, 0,01, $0,05,0,1,0,2,0,4,0,8$, dan 1,6 ppm. Selanjutnya sampel dianalisis dengan Atomic Absorption Spectrometer Buck Scientific 205

\subsection{Pembuatan Deret Standar Cd pada Simbion Laut}

Pembuatan deret standar adalah 0, 0.05, 0,1, 0,2, 0,5 dan 1 ppm. Selanjutnya sampel di analisis dengan Atomic Absorption Spectrometer Buck Scientific 205.

\subsection{Analisis Kadar Logam Cd Pada Bakteri Simbion}

Suspensi bakteri di tuang pada cawan petri yang di tambahkan dengan nutrien broth (NB), kemudian pada cawan petri menghasilkan koloni bakteri. Koloni bakteri yang diperoleh ditimbang $10 \mathrm{~g}$ lalu didestruksi dengan 10 $\mathrm{mL} \mathrm{HNO}_{3} 65 \%$. Hasil destruksi kemudian disaring dengan menggunakan kertas whatman 42 sehingga di peroleh larutan jernih. Filtrat lalu ditempatkan dalam labu ukur 50 $\mathrm{mL}$ dan siap di analisis.

\section{Hasil dan Pembahasan}

Suhu perairan Kabupaten Bantaeng hasil pengukuran pada saat pengambilan sampel adalah berkisar antara 29$30^{\circ} \mathrm{C}$. Suhu air laut di perairan Kabupaten Bantaeng berada pada kondisi normal karena pada suhu permukaaan air laut normal antara $21-32^{\circ} \mathrm{C}$ sedangkan suhu perairan di Indonesia $27-31^{\circ} \mathrm{C}$. Rentang suhu ini cukup mendukung pertumbuhan rumput laut $[18,19]$. Pertumbuhan yang optimum akan meningkatkan kemampuannya dalam mengakumulasi logam. Suhu merupakan faktor penting dalam pengaturan proses kehidupan dan penyebaran organism. Kehadiran spesies tertentu dalam suatu wilayah memerlukan kondisi suhu tertentu pula. Suhu tidak hanya berpengaruh pada proses metabolisme organisme saja melainkan juga terhadap aktivitas senyawa-senyawa kimia terlarut.

Tabel 2. Kondisi sampling air laut

\begin{tabular}{lccc}
\hline \multicolumn{1}{c}{ Lokasi } & Suhu $\left({ }^{\mathbf{0}} \mathbf{C}\right)$ & $\mathbf{p H}$ & Salinitas $(\%$ \%o \\
\hline Nipa Nipa & 29 & 7,5 & 34 \\
Kampung Bakara & 29 & 7,5 & 33 \\
Boroloe & 30 & 7 & 34 \\
Tapaloe & 29 & 7,5 & 35 \\
Baruga Utara & 29 & 7 & 35 \\
Baruga Selatan & 30 & 7,5 & 33 \\
\hline
\end{tabular}

Derajat keasaman (pH) merupakan salah satu parameter yang mempengaruhi kehidupan rumput laut. Umumnya nilai $\mathrm{pH}$ lingkungan perairan laut yang mendukung kehidupan biota perairan 7,7-8,4 [20]. Derajad keasaman $(\mathrm{pH})$ perairan Kabupaten Bantaeng hasil pengukuran pada saat pengambilan sampel sekitar 7-7,5. Tingkat keasaman suatu perairan dapat di perbaharui oleh banyaknya kandungan logam atau buangan organik dalam perairan tersebut. Salinitas merupakan salah satu variabel yang menentukan kehidupan organisme akuatik terutama pada keseimbangan osmotik dengan lingkungannya. Salinitas pada perairan yang menunjukan pertumbuhan optimum pada rumput laut adalah 28-38\% [21]. Jika dibandingkan dengan salinitas pada perairan Kabupaten Bantaeng yakni sekitar 33-35\%, salinitas dalam lingkungan optimum untuk pertumbuhan rumput laut.

Konsentrasi logam kadmium (Cd) masing-masing desa dari sampel 1 sampai dengan sampel 6 berkisar antara 0,1824-0,2920 ppm, kadar tertinggi pada Desa Nipa-Nipa sebesar 0,2920 ppm sedangkan yang terendah Desa Baruga Selatan sebesar 0,1824 ppm. Kadmium (Cd) merupakan salah satu logam berat yang dapat mencemari lingkungan. Pada Gambar 2 menunjukan masing-masing nilai kadmium dimana menurut Food and Agriculture Organisasi (FAO) 
kadar logam kadmium pada rumput laut sebesar 0,1 ppm Tingginya kadar kadmium pada rumput laut karena proses akumulasi pada perairan melalui sedimen dimana tempat tumbuh rumput laut melekat pada sedimen atau lumpurlumpur yang ada pada perairan. Logam kadmium diabsorpsi oleh rumput laut dari lingkungan air atau fitoplankton dan tumbuhan renik yang sudah terakumulasi kadmium [22].

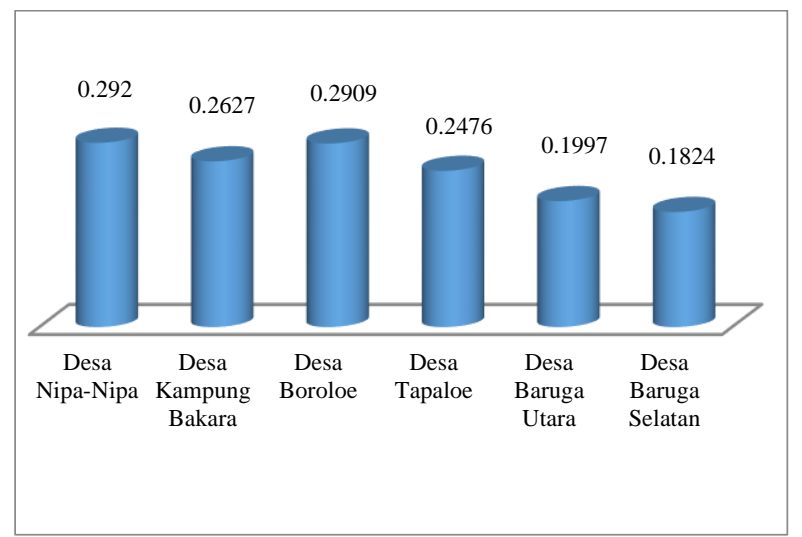

Gambar 1. Histogram konsentrasi logam kadmium (Cd)

Konsentrasi logam kadmium (Cd) pada simbion masing-masing desa dari sampel 1 sampai dengan sampel 6 berkisar antara 0,0141-0,0192 ppm, kadar tertinggi pada Desa Baruga Utara sebesar 0,0192 ppm sedangkan yang terendah Desa Nipa-Nipa sebesar 0,0141 ppm. Pada perairan Bantaeng faktor yang mempengaruhi proses sirkulasi dalam perairan dan berpengaruh terhadap jumlah nutrient yang dibawanya adalah arus. Hubungan antara rumput laut dan bakteri dimana rumput laut memberikan nutrisi pada bakteri sedangkan bakteri mendorong pertumbuhan rumput laut dan melindungi dari serangan bakteri patogen. Bakteri masuk pada rumput laut melalui thallus. Bakteri terikat pada gen di spesies rumput laut, dinding sel dan metabolit sekunder pada rumput laut memicu interaksi antara bakteri dan rumput laut [23].

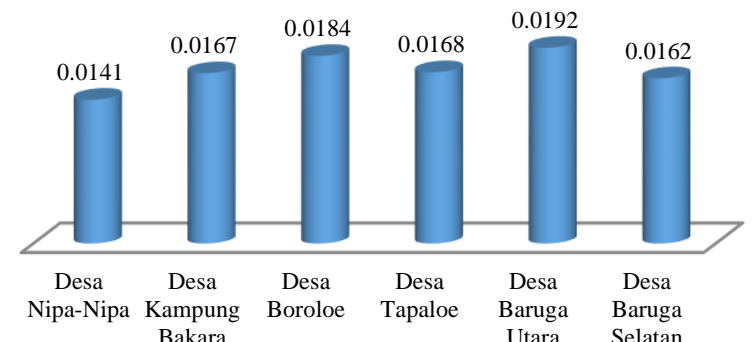

Gambar 1. Histogram konsentrasi logam kadmium (Cd) pada bakteri simbion

Logam kadmium termasuk dalam logam berat. Logam berat termasuk logam yang diregulasi oleh organisme air dalam logam yang pada konsentrasi tertentu dalam air tidak diakumulasi terus menerus oleh organisme tersebut dan dikeluarkan dari tubuh mereka (ekskresi) sehingga kandungannya dalam jaringannya tetap. Penyerapan logam berat oleh mikroorganisme terjadi pada dua tahap. Tahap penyerapan pasif yang berlangsung lambat, penyerapan pasif berawal ketika logam berat berinteraksi dengan dinding sel. Dinding sel mengandung enzim ekstraseluler yang berfungsi dalam penyerapan unsur-unsur yang dibutuhkan sel. Pada penyerapan aktif, logam ditransformasikan melalui membran sel menuju sitoplasma [24].

Secara umum, bakteri simbion dapat mengakumulasi logam karena bakteri berhubungan dengan rantai makanan terutama pada lingkungan air yang tinggi kandungan organiknya. Susunan DNA dari bakteri yang terdiri atas adenin (A), guanine (G), cytosine (C) dan uracil (U) kemungkinan dapat berikatan dengan gugus-gugus fungsi yang berinteraksi dengan logam. Saat logam berada pada densitas yang mengkategorikan sebagai logam berat, logam tersebut dapat bervariasi di lingkungan dapat menghasilkan modifikasi serius dalam komunitas mikrobial dan aktivitasnya seperti mutagenitas atau resistensi. Bakteri dapat digunakan sebagai indikator potensial dan memonitor logam berat di habitatnya [25].

\section{Kesimpulan}

Konsentrasi logam kadmium (Cd) pada rumput laut jenis Eucheuma cottonii, pada alga dari sampel 1 sampai dengan sampel 6 berkisar antara 0,1824-0,2920 ppm dan konsentrasi logam kadmium (Cd) pada simbion bakteri pada rumput laut jenis Eucheuma cottonii, dari sampel 1 sampai dengan sampel 6 berkisar antara 0,0192-0,0141 ppm.

\section{Ucapan Terima Kasih}

Penulis menyampaikan terima kasih kepada ibu Dr. Nursiah La Nafie, M. Sc dan Ibu Dr. Seniwati Dali, M.Si yang telah memberikan pengarahan dan petunjuk dalam menyelesaikan jurnal ilmiah.

\section{Daftar Pustaka}

1. Abowei JFN, Ezekiel EN. The potentials and utilization of Seaweeds. J. Sci. Agri., 2013, 4(2);58-66.

2. Satheesh S, Wesley SG. Diversity and distribution of seaweeds in the Kudankulam coastal waters, South-Eastern coast of India. Biodiversity Journal, 2012, 3(1);79-84.

3. Akhar NJ, Iqbal. Removal and Recovery of $\mathrm{Pb}$ (II) from Agneous Solution by Loofa Sponge-Immobilized Biomass of Chrolla Sorokiniana: charactization studies, J. Hazards Mat, 2004, 12(1);85-94.

4. Jang SS, Shirai Y, Uchida M, Wakisaka M. Production of mono sugar from acid hydrolysis of seaweed. African $J$. of Biotech., 2012, 11(8);1953-63.

5. Candra PK, Sarwana, Sarinah. Study Bioetanol Production Using Red Seaweed Eucheuma cottonii From Bontang Sea Water, J. Coastal Develop., 2011, 15(1);45-50.

6. Raya I, Ramlah. The Bioaccumulation of Cd (II) ions on Eucheuma cottoni. Marine Chemical Acta, 2012, 13(2);1318. 
7. Sitrat DW, Sukesi. Antioksidan Dalam Bakso Rumput Laut Merah Eucheuma cottoni, Jurnal Sains dan Seni Pomits, 2012, 1(1);1-4.

8. Siregar FW, Sabdono A, Pringggenies D, Potensi Antibakteri Ekstrak Rumput Laut Terhadap Bakteri Penyakit Kulit Pseudomsaeroginosa, Staphylococcus epidermis, dan Micrococcus loteus, J. Marine Res., 2012, 1(2);152-160.

9. Naid T, Kasim S, Marzuki A, Sumarheni. Produksi Antibiotika Secara Fermentasi dari Biakan Mikroorganisme Simbion Rumput Laut Eucheuma cottonii. Majalah Farmasi dan Farmakologi, 2013, 17(3);61-68.

10. Lamai SS, Shirai Y, Uchida M, Wakisaka M. Production of mono sugar from acid hydrolysis of seaweed, African $J$. of Biotech., 2012, 11(8);1953-63

11. Nopriani LS, Teknik Cepat Untuk Identifikasi Pencemaran Logam Berat di Lahan Apel Batu. Disertasi. Malang: Fakultas Pertanian, Universitas Brawiajaya. 2011

12. Rao PV, Mantri V, Ganesan K. Mineral Composition of Edible Seaweed Porphyra vietnamensis. Food Chemistry 2007, 102;215-218.

13. Adriani NA, Patong AR, Maming. Analisis Kadar Logam Nikel Dalam Bakteri Simbion pada Spons Callyspongia Sp, Marine Chemical Acta. 2013, 13(1);1-6.

14. Zheng L, Han X, Chen H, Yan X. Marine Bacteria Associated with Marine Microorganisme: The Potential Antimicrobal Resources. Annals of Microbiology, 2005, 55(2);119-124.

15. Burgess JG, Jordan EM, Bregu M. Microbial Antaginism: a Neglected Avenue of Natural Products Research, $J$. Biotechnol. 1999, 70;27-32.
16. Dinas Kelautan dan Perikanan Provinsi Sulawesi Selatan. Data Potensi Perikanan Sulawesi Selatan. Makassar: Dinas Kelautan dan Perikanan Provinsi Sulawesi Selatan. 2016

17. Abirami RG, Kowsalya S. Nutrient and Nutraceutical Potential of Seaweed Biomassa Ulfa Lactuca and Kappaphycus alvarezii. Agricult Sci and Technol, 2011, 5(1);1-6.

18. Susilowati T, Rejeki S, Dewi EN, Zulfitriani. Pengaruh Kedalaman Terhadap Pertumbuhan Rumput Laut (Eucheuma cottonii) yang di Budidayakan Dengan Metode Longline di Pantai Mlunggu, Kabupaten Jepara, Jurnal Saintek Perikanan, 2012, 8(1);7-12.

19. de Fretes H, Susanto AB, Budhi P, Heriyanto, Brotosudarmo THP, Limantara L. Estimasi Produk Degradasi Ekstrak Kasar Pigmen Alga Merah Kappaphycus alvarezii (Doty) Doty Varian Merah, Coklat, dan Hijau. Ilmu Kelautan, 2012, 17(1);31-38.

20. Kementerian Lingkungan Hidup Republik Indonesia. Keputusan Kementrian Lingkungan Hidup No. 51 Tahun 2004. Jakarta: Kementerian Lingkungan Hidup Republik Indonesia, 2004.

21. Widowati. Efek Toksik Logam: Pencegahan dan Penanggulangan Pencemaran. Yogyakarta: Penerbit Andi; 2008.

22. Kunarso DJ, Kajian Kesuburan Ekosistem Perairan Laut Sulawesi Tenggara Berdasarkan Aspek Bakteriologi, Jurnal Ilmu dan Teknologi Kelautan Tropis, 2011, 3(2);32-47.

23. Purbonegegoro T. Pengaruh Logam Berat Kadmium Terhadap Metabolisme dan Fotosintetis di Laut. Jurnal Oseana, 2008, 33;25-31. 